\title{
NEW OPPORTUNITIES TO IDENTIFY AND TYPE STAPHYLOCOCCUS spp. BY USING MALDI-TOF MASS SPECTROMETRY
}

\author{
A.S. Stepanov, N.V. Vasilyeva \\ North-Western State Medical University named after I.I. Mechnikov, St. Petersburg, Russian Federation
}

\begin{abstract}
Mass spectrometry profiles of microorganisms obtained by time-of-flight matrix-associated laser desorption/ionization (MALDI-TOF) mass spectrometry are a source of information about peptide profiles can be used for microbial identification and typing. A variety of technical and bioinformational solutions complicate developing of a united mass-spectro-profile database. Staphylococcus spp. strains are good studied objects for identification by MALDI-TOF mass spectrometry, frequently resulting in nosocomial infections, especially in immunocompromised patients. Rapid differentiation of nosocomial, multiresistant and highly virulent isolates of Staphylococcus spp. allows to reduce the lethality in weakened and immunocompromised patients. The study was aimed at assessing comparability and reproducibility of identification and typing results for Staphylococcus spp by MALDI-TOF mass spectrometry. Comparing 292 Staphylococcus spp. isolates in clinical specimens obtained fron the multidisciplinary hospital at the NWSMU im. I.I. Mechnikov was carried out by using MALDI-TOF mass spectrometer BactoSCREEN ID (Litech, Russia) and Bruker Biotyper 3.1 (Bruker GmbH, Germany). Comparability of Staphylococcus spp. identification showed that $95.9 \% ; 12$ isolates (4.1\%) by "Bruker Biotyper 3.1" and 3 isolates (1.1\%) by using "BactoSCREEN ID" were incorrectly identified. Repeated identification leveled the differences between the systems used. In addition, it was shown that the method of protein extraction did not affect reliability of Staphylococcus spp. species identification by using databases $\left(\chi^{2}, \mathrm{p}>0.05\right)$ compared to intraspecific typing $\left(\chi^{2}, \mathrm{p}<0.0001\right)$. Using different extraction protocols showed that Staphylococcus spp. mass-spectra differed by peak intensity level within the mass range up to $4000 \mathrm{~m} / \mathrm{z}, 5300 \pm 600 \mathrm{~m} / \mathrm{z}$ and $6500 \pm 500 \mathrm{~m} / \mathrm{z}$, as well as higher than $7000 \mathrm{~m} / \mathrm{z}$. Peaks of low-molecular weight peptides were detected under full protein extraction compared to sample preparation on plate extraction. To develop a unified protocol for mass-spectrometry profile processing, a reliability of the basic statistical variables (mode, median, maximum, minimum and arithmetic mean) was evaluated. Analysis of the median mass spectrometry profiles is recommended for Staphylococcus spp. intraspecific typing by using MALDI-TOF mass spectrometry as the most reproducible and consistent approach. As a result, two systems for MALDI-TOF mass spectrometry reliably identify Staphylococcus spp., but standardization of sample preparation and bioinformation analysis is required for Staphylococcus spp. typing.
\end{abstract}

Key words: Staphylococcus spp., MALDI-TOF mass spectrometry, typing, mass-spectra, cluster analysis, identification.

\author{
Адрес для переписки: \\ Степанов Александр Сергеевич \\ 195067, Россия, Санкт-Петербург, Пискаревский пр., 47, \\ Северо-Западный государственный медицинский университет \\ им. И.И. Мечникова. \\ Тел.: 8 (921) 897-10-13 (моб.). \\ E-mail: aleksandr.stepanov@szgmu.ru
}

\section{Библиографическое описание:}

Степанов А.С., Васильева Н.В. Новые возможности для идентификации и типирования Staphylococcus spp. методом MALDI-TOF мaccспектрометрии // Инфекция и иммунитет. 2018. Т. 8, № 4. С. 489-496. doi: 10.15789/2220-7619-2018-4-489-496

\section{Contacts:}

Aleksandr S. Stepanov

195067, Russian Federation, St. Petersburg, Piskarevsky pr., 47, North-Western State Medical University named after I.I. Mechnikov. Phone: +7 (921) 897-10-13 (mobile).

E-mail: aleksandr.stepanov@szgmu.ru

\section{Citation:}

Stepanov A.S., Vasilyeva N.V. New opportunities to identify and type Staphylococcus spp. by using MALDI-TOF mass spectrometry // Russian Journal of Infection and Immunity = Infektsiya i immunitet, 2018, vol. 8, no. 4, pp. 489-496. doi: 10.15789/2220-7619-2018-4-489-496 


\title{
НОВЫЕ ВОЗМОЖНОСТИ ДЛЯ ИДЕНТИФИКАЦИИ И ТИПИРОВАНИЯ STAPHYLOCOCCUS spp. МЕТОДОМ MALDI-TOF МАСС-СПЕКТРОМЕТРИИ
}

\author{
Степанов А.С., Васильева Н.В. \\ Северо-Западный государственный медицинский университет им. И.И. Мечникова, Санкт-Петербург, Россия
}

Резюме. Масс-спектро-профили микроорганизмов, получаемые с помощью времяпролетной матрице-ассоциированной лазерной десорбции/ионизациии (MALDI-TOF) масс-спектрометрии являются источником информации о пептидных профилях, которая может быть использована для идентификации и типирования. Разнообразие технических и биоинформационных решений затрудняет формирование единой базы масс-спектро-профилей. Бактерии рода Staphylococcus являются одними из наиболее изученных объектов для идентификации с помощью MALDI-TOF масс-спектрометрии, а также являются частыми возбудителями внутрибольничных инфекций, в особенности среди иммунокомпрометрированных пациентов. Методы быстрой дифференцировки нозокомиальных, полирезистентных и высоковирулентных изолятов Staphylococcus spp. позволят снизить летальность среди ослабленных и иммунокомпрометированных пациентов. Целью исследования была оценка сопоставимости и воспроизводимости результатов идентификации и типирования Staphylococcus spp. с помощью MALDI-TOF масс-спектрометрии. Сравнительные исследования 292 изолятов Staphylococcus spp., выделенных из клинических образцов на базе многопрофильного стационара СЗГМУ им. И.И. Мечникова проводили с помощью MALDI-TOF масс-спектрометрометров «BactoSCREEN ID» (OOO «Литех», Россия) и Bruker Biotyper 3.1 (Bruker GmBH, Германия). Сопоставимость результатов видовой идентификации Staphylococcus spp. составляла 95,9\%; причем среди неправильно идентифицированных изолятов изолятов 12 (4,1\%) составляли идентифцированные с помощью Bruker Biotyper 3.1 и 3 изолята (1,1\%) Staphylococcus spp. с помощью BactoSCREEN ID. Повторная идентифкация нивелировала различия между используемыми системами. Выявили, что способ экстракции белков не влиял на надежность видовой идентификации Staphylococcus spp. с использованием сравниваемых библиотек данных ( $\chi^{2}, \mathrm{p}>$ $0,05)$ в отличие от внутривидового типирования $\left(\chi^{2}, \mathrm{p}<0,0001\right)$. Масс-спектры Staphylococcus spp. при использовании различных протоколов экстракции различались по уровню интенсивности пиков диапазонов масс до $4000 \mathrm{~m} / \mathrm{z}, 5300 \pm 600 \mathrm{~m} / \mathrm{z}$ и $6500 \pm 500 \mathrm{~m} / \mathrm{z}$ и более 7000 m/z. Пики низкомолекулярных пептидов выявляли при полной экстракции белка в отличии от пробоподготовки на поверхности мишени. Для формирования унифицированного протокола обработки масс-спектро-профилей проводили оценку надежности базовых статистических величин (мода, медиана, максимум, минимум и среднее арифметическое). Анализ медианы масс-спектро-профилей рекомендуется использовать для воспроизводимости и стабильности результатов внутривидового типирования Staphylococcus spp. с помощью MALDI-TOF масс-спектрометрии. В результате сравнительных исследований выявили, что две системы для MALDI-TOF масс-спектрометрия надежно идентифицируют Staphylococcus spp., а для типирования требуется унификация пробоподготовки и биоинформационного анализа.

Ключевые слова: Staphylococcus spp., MALDI-TOF масс-спектрометрия, типирование, масс-спектр, кластерный анализ, идентификация.

\section{Introduction}

Staphylococcus spp. are important causative agents of human infections especially in intensive care units (ICU) [2]. The spread of methicillin-resistant isolates of Staphylococcus spp. is the cause of the patients condition burden in hospital media $[1,6]$.

MALDI-TOF mass spectrometry is an effective method for identifying Staphylococcus spp. Nevertheless, increasing of the number of nosocomial infections associated with Staphylococcus spp. requires rapid and reliable identification and obtaining additional information about resistance potential and epidemiological significance $[10,18]$. The problem solution is impossible without unified typing protocol development and a multicentral compari- son of a MALDI-TOF mass spectrometry results, but to the date MALDI-TOF mass spectrometers are represented by several independent technical solutions with independent mass spectrometry libraries [18]. Methods of sample preparation, technological features of devices and approaches to bioinformatic analysis among manufacturing companies are different, which interfere obtaining of a multicentral data analysis. Moreover, the proposed methods for typing Staphylococcus spp., in particular MRSA, do not have united approaches [14, 19]. Data about reproducibility of MALDI-TOF mass spectrometry as a method of typing are contradictory [3, 5, 17]. Thus, to form a unified system for identification and typing of Staphylococcus spp. where is necessary to evaluate the reliability, reproducibility and comparability of the results of identification and 
typing conducted using various technical solutions and data libraries.

At present, MALDI-TOF mass spectrometers are presented as technical solutions from manufacturers: "Bruker" (Germany), "bioMerieux" (France), "Shimadzu” (Japan), "Litech" (Russia). "Bruker", "bioMerieux" and "Shimadzu" use mass-spectra databases "Saramis" and "MS RUO" for identification each are very close [11], but "Litech" uses an original database, different from previously noted. For the identification of microorganisms cultures, manufacturers sugest different methods of sample preparation, which is due to the features of obtaining mass-spectro-profiles included in the data libraries [11]. Due to the libraries of MALDI-TOF mass spectrometers are separated, where is difficult to compare the effectiveness of MALDI-TOF mass spectrometry for the typing of Staphylococcus spp. and screening for methicillin resistance [11].

Thus, the study purpose was a comparative assessment of the comparability of the results of species identification and typing of Staphylococcus spp. using various libraries, sample preparation protocols and technical solutions in the field of MALDITOF mass spectrometry.

\section{Materials and Methods}

Staphylococcus spp. isolates $(n=292)$ were obtained from samples of patients from a multidisciplinary hospital in St. Petersburg. First inoculation was carried out on a set of media: Colombia agar with 5\% sheep erythrocytes (Biomedia, Russia), yolk-salt agar (NITF, Russia). Plates were incubated for 24 hours at $37^{\circ} \mathrm{C}$.

MALDI-TOF mass spectrometry was performed using Bruker AutoFleX Speed mass spectrometers (Bruker GmBH, Germany) and BactoSCREEN ID (Litech, Russia). Incubation of Staphylococcus spp. on Colombia agar with $5 \%$ sheep erythrocytes for 24 hours at $37^{\circ} \mathrm{C}$. Extraction of peptides was carried out by the following methods:

1. Direct extraction on the target using a $70 \%$ solution of formic acid, drying in air for 2 minutes [4].

2. Total extraction by alcohol-acid method [15] with purification by acetonitrile solution.

3. Short protocol of alcohol-acid extraction without precipitation of cells components and acetonitrile purification [13].

After this, $\alpha$-cyano-4-hydroxycinnamic acid was added and dried in air.

Using a Bruker AutoFleX Speed mass spectrometer, mass spectra were collected using a linear TOF protocol with a laser frequency of $20 \mathrm{~Hz}$ and an estimate in the mass range of 2000 to $20000 \mathrm{~m} / \mathrm{z}$. The voltage on the acceleration was $20 \mathrm{kV}$, the volt- age IS2 was $18.6 \mathrm{kV}$. For total spectrum, 1200 separate spectra were collected from the entire target area. The identification of cultures was carried out according to the protocol "Bruker Taxonomy", included in the software package "Bruker Real Time Classification 3.1". In the case of "Score" above 2.0, the identification was considered good, for isolates that had "Score" from 1.4 to 1.9 were re-identified. To increase the reliability, this procedure was repeated twice for each isolate.

Sampling and analysis of mass spectra obtained with the MALDI-TOF mass spectrometer "Bruker AutoFleX Speed" was carried out using the "R 3.3.3" software package with the MaldiQuantForeign extension package [7]. The Savitzky-Golay protocol was used to smoothing, and the baseline level was performed using a statistically-dependent non-linear cross-referenced algorithm (SNIP) [12]. Noises were excluded using the "Friedman's Super Smoother" method included in the R 3.3.2 MaldiQuantForeign software package. Analysis of variance was used to estimate the variability of peak intensities on the obtained mass spectra in the R-commander software package.

Using the BactoSCREEN ID mass spectrometer, identification of Staphylococcus spp. provided accordance with manufacturer recomendations. Identification was carried out twice for each culture in order to improve reliability. ATCC 29213 $S$. aureus strain was used as a control sample. A preliminary grouping of the results of MALDI-TOF mass spectrometry using the mass spectrometer data was carried out using software package R 3.3.3 by the original program code.

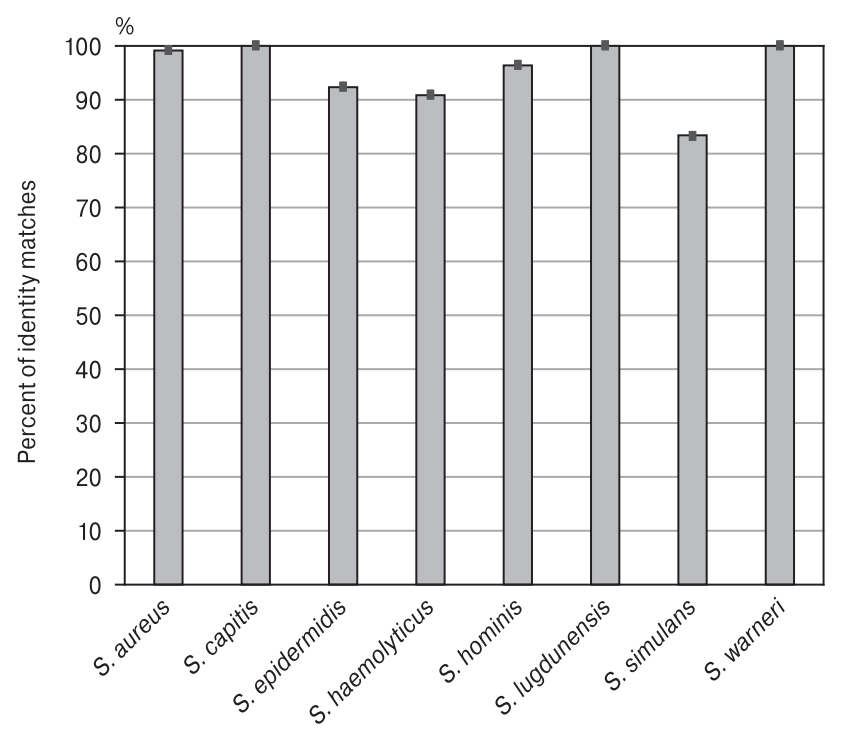

Figure 1. Staphylococcus spp. identification results using Bruker Autoflex Speed and BactoSCREEN ID (Litech Ltd.) 


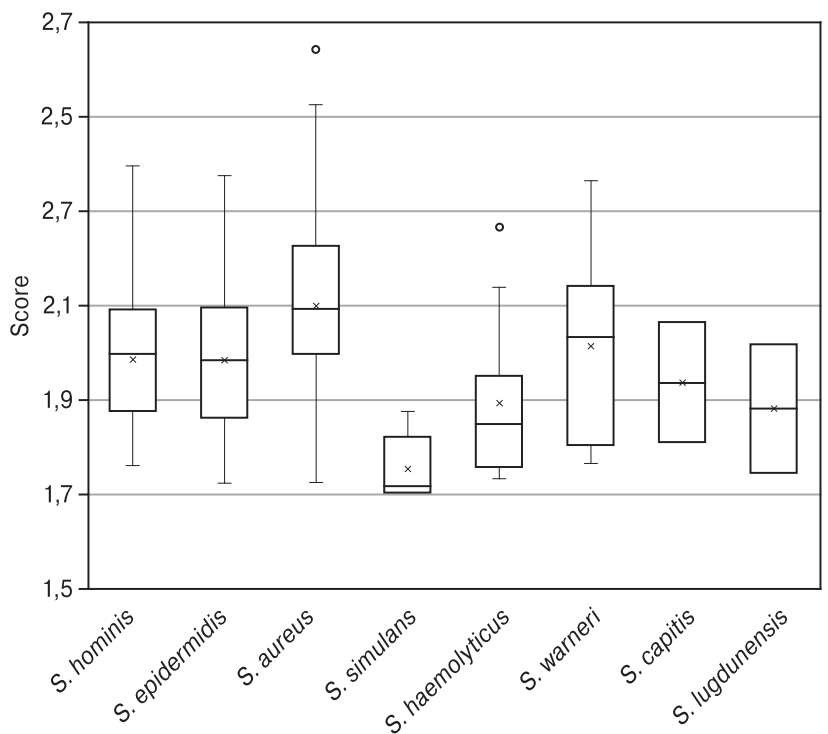

Figure 2. Reliability of Staphylococcus spp. identification using "Bruker AutofleX Speed" (Biotyper 3.1) library

\section{Results}

Identification of Staphylococcus spp. 292 isolates using MALDI-TOF mass spectrometer "BactoSCREEN ID" and "Bruker AutofleX Speed" have revealed a high level of comparability (fig. 1).

Identification of 12 Staphylococcus spp. isolates (4.1\%) was unreliable using Bruker AutofleX Speed (Biotyper 3.1): five $S$. epidermidis, one $S$. aureus, two $S$. auricularis, one $S$. haemolythicus, three $S$. simulans, but the differences have been eliminated by repeated identification.

Using the database of the "BactoSCREEN ID" device, 3 isolates (1.1\%) were not identified: two $S$. simulans and one $S$. epidermidis, which were reliably identified by Bruker Biotyper 3.1. The isolates were identified correctly after second round of identification.

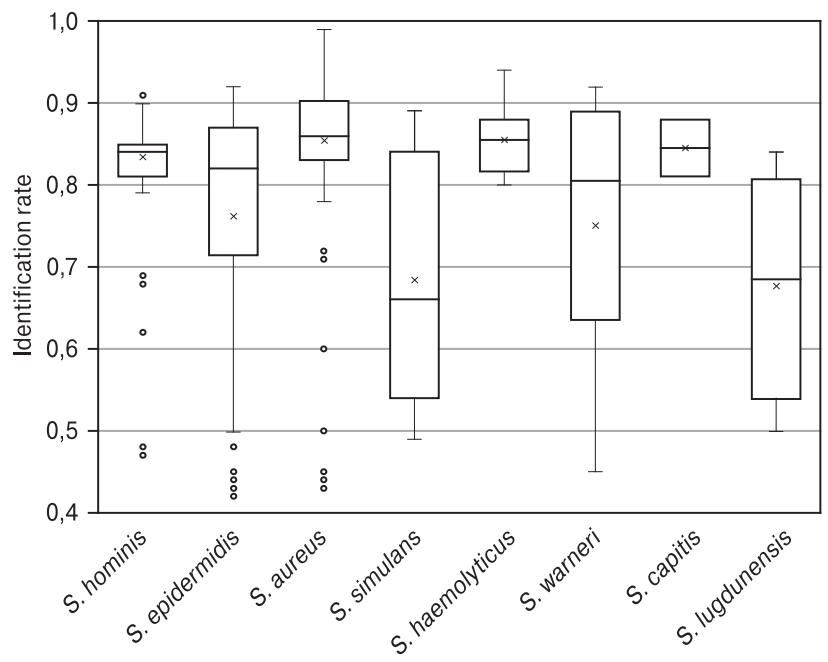

Figure 3. Reliability of Staphylococcus spp. identification using the "BactoSCREEN ID" library
When using "Bruker AutofleX Speed" (Biotyper 3.1), the lowest reliability of identification was revealed for $S$. simulans and $S$. haemolythicus (fig. 2).

Analyzing the stock of Staphylococcus spp. using the database of the "BactoSCREEN ID", the low reliability of the $S$. simulans species identification and atypical spectra of $S$. hominis, $S$. epidermidis and $S$. aureus was revealed, which were lay outside the general population of values (fig. 3).

Evaluating the effect of extraction protocols on the identification reliability, where was estimated the level of reliability of identification using databases "Bruker Biotyper 3.1" and "BactoSCREEN ID" (fig. 4) did not depend on the extraction protocol (Fisher criterion, $p>0.05$ ). Statistically significant differences in the reliability of identification were revealed between the databases during the onplate extraction (Fisher criterion, $\mathrm{p}<0.001$ ).

To assess the differences in mass spectra profiles obtained with different extraction protocols, the differences in the structure of the mass spectrometry profiles of $S$. epidermidis $(\mathrm{n}=82)$ were compared; linear and diagonal discriminatory analysis were used. Total extraction is characterized by a rather low intensity of peaks in the regions: $5300 \pm 600 \mathrm{~m} / \mathrm{z}$ and $6500 \pm 500 \mathrm{~m} / \mathrm{z}$ and higher than $7000 \mathrm{~m} / \mathrm{z}$. On the other hand, the intensity of signals of low molecular weight peptides $(3500 \pm 100 \mathrm{~m} / \mathrm{z})$ was higher at complete extraction (fig. 5). The combined extraction method was characterized as an intermediate, including the positive sides of both full extraction and direct application.

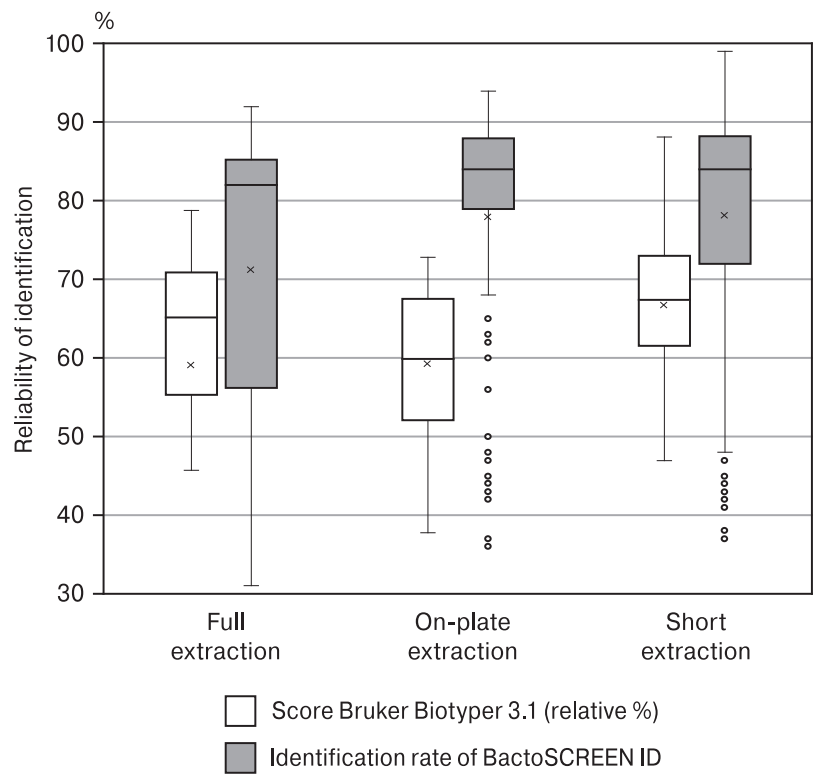

Figure 4. Dependence of the "Score" BrukerBiotyper 3.1 and identification reliability using the database of the device "BactoSCREEN ID" from the extraction protocol 


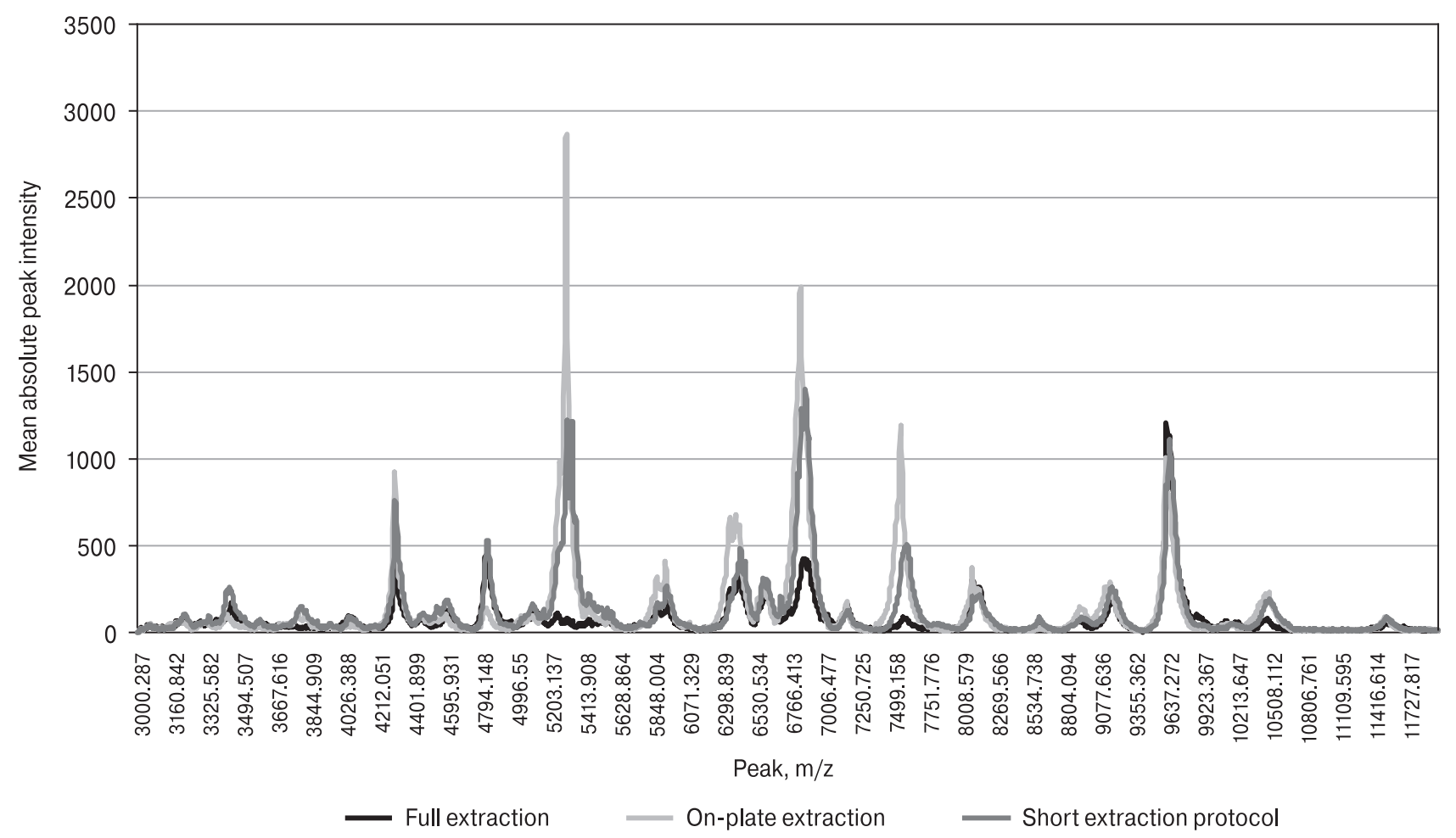

Figure 5. Comparison of mass spectrometry profiles of S. epidermidis, depending on the method of extraction of peptides

The structure of the mass spectrometry profiles of other Staphylococcus spp. species also differed depending on the method of protein extraction: the intensity of the median mass range peak peptides was the most intensive at direct application and extraction on the target, while the use of a complete extraction protocol allows more effective detection of peaks of low molecular weight proteins (up to $4000 \mathrm{~m} / \mathrm{z}$ ) .

To estimate the effect of peptide extraction on the identification result, the possibilities of harmonizing the sample of mass spectra based on main statistical parameters of the mass spectrometer profile were evaluated. In contrast to the previously proposed harmonization methods for high-intensity stable sites, median harmonization was used [18]. Since the scatter of the peaks in the $6800-9500 \mathrm{~m} / \mathrm{z}$ ranges was significant and the harmonization was not universal for all species (fig. 6).

Comparing the structure of the $S$. epidermidis population by analysis of harmonized and unharmonized mass-spectrometry profiles, revealed statistically significant differences in the intraspecific clusters structure (fig. 7).

The discrimination of $S$. epidermidis into clusters was characterized by high stability: only $10 \%$ of the isolates were assigned to different clusters at the re-identification and mass spectrometer profile evaluation.
Intraspecific structure of other Staphylococcus spp. also differed depending on using of mass spectra harmonization protocols. Based on bootstrap analysis, where was obtained the harmonization allow to discriminate only two general clusters in all Staphylococcus spp. with stapility during 100fold repetitions (alpha $>0.95$ ). Nevertheless, the protein extraction method had a statistically significant effect on the intraspecific Staphylococcus spp. differentiation despite the harmonization using $\left(\chi^{2}\right.$, $\mathrm{p}<0.0001)$.

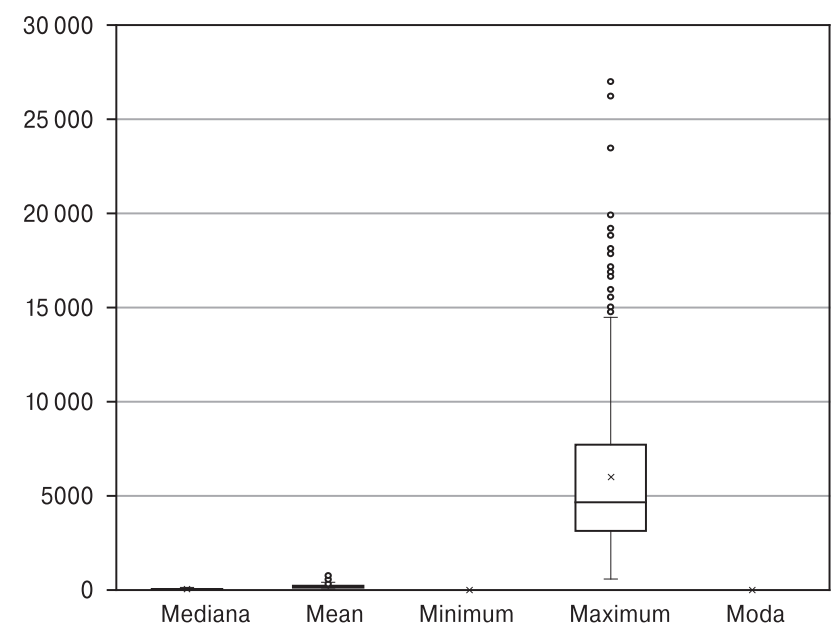

Figure 6. Evaluation of the stability Staphylococcus spp. mass-spectra profiles 

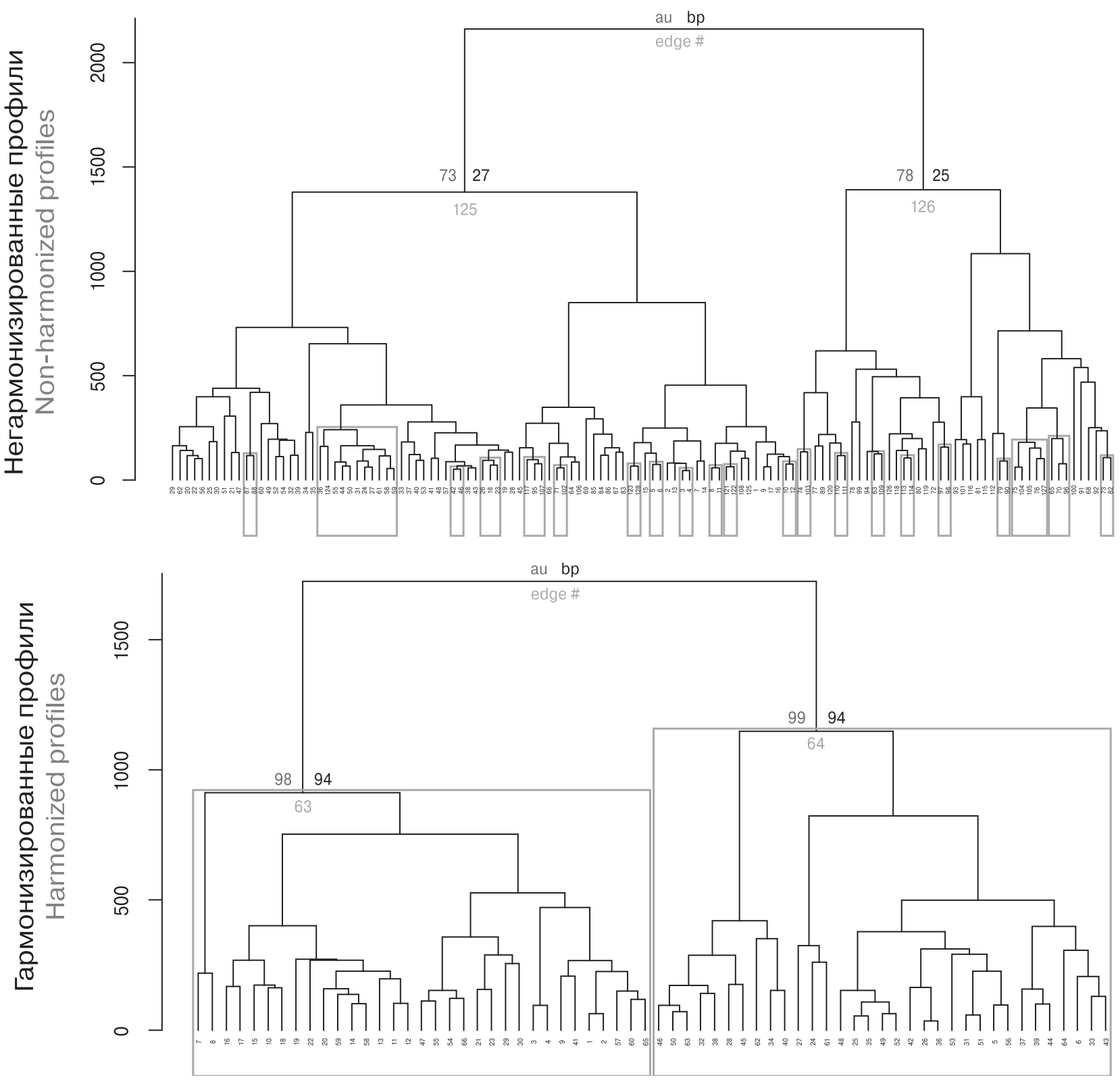

Figure 7. Subspecies structure of $\mathbf{S}$. epidermidis

\section{Discussion}

The comparison of the identification results 292 Staphylococcus spp. isolates revealed 95.9\% of the coincidence of species identification using both the Bruker "Biotyper 3.1" databases and the "BactoSCREEN ID" devices. The lowest rating of identification reliability was revealed for $S$. simulans using both instrument solutions.

Reliability of species identification, expressed as "Score" (Bruker Biotyper 3.1) and "Identity Reliability" (BactoSCREEN ID), did not differ significantly depending on the protocol of protein extraction, but statistically significant differences in the intensity of individual peaks of mass spectra were found. Moreover, when using extraction on the target, some peaks of low molecular weight proteins were not detected, which can be used for typing or evaluating resistance [16]. Similar results of bacterial identification were obtained by comparing the instruments of Vitek MS (bioMerieux, France) and Bruker Microflex: for gram-positive bacteria, the comparability of identification results between instruments was 97.4\% [9], for Gram-negative bacteria $-99.4 \%$ [8]. Thus, despite the differences in bioinformation and technical solutions, the species identification using MALDI-TOF mass spectrometry is reliable, and the results are comparable. The differences obtained by comparing the identification results can be explained by the library structure features of mass-spectrometer, which are formed on the basis of the complete extraction protocols of the protein (Bruker Biotyper 3.1) and extraction on-plate extraction (BactoSCREEN ID). 
The results of our research show that to compare the results of typing on different systems for MALDITOF mass spectrometry, where is necessary to carry out mass-spectrometry harmonization based on the mass-spectrum median estimate similary to the Savitzky-Golay protocols [7]. Using of previously proposed calibrations of peaks intensity on the range $6800 \pm 300 \mathrm{~m} / \mathrm{z}$ [14] is less reliable due to the high variability of the absolute intensity of these peaks.

The structure of the obtained clusters in the case of S. epidermidis was stable for $90 \%$ isolates during MALDI-TOF mass-spectrometry repitition.
However, statistically significant effect of used extraction protocol on the results of intraspecific typing of all Staphylococcus spp. was observed.

Thus, the use of MALDI-TOF mass spectrometry for Staphylococcus spp. identification was characterized by high reproducibility of results using various technical solutions in the field of mass spectrometry, extraction protocols and various data libraries. However, quantitative analysis of peaks for intraspecific typing requires not only a single bioinformational approach, but also unification of sample preparation protocols.

\section{Список литературы/References}

1. Гостев В.В., Калиногорская О.С., Черненькая Т.В., Науменко 3.С., Ворошилова Т.М., Захарова Ю.А., Хохлова О.Е., Круглов А.Н., Сидоренко С.В. Антибиотикорезистентность метициллинорезистентных Staphylococcus aureus, циркулирующих в Российской Федерации // Антибиотики и химиотерапия. 2015. T. 60, № 1-2. C. 3-9. [Gostev V.V., Kalinogorskaya O.S., Chernenkaya T.V., Naumenko Z.S., Voroshilova T.M., Zakharova Yu.A., Khokhlova O.E., Kruglov A.N., Sidorenko S.V. Antibiotic resistance of MRSA in Russian Federation. Antibiotiki i khimioterapiya $=$ Antibiotics and Chemotherapy, 2015, vol. 60, no. 1-2, pp. 3-9. (In Russ.)]

2. Козлова Н.С., Баранцевич Е.П., Баранцевич Н.Е. Антибиотикорезистентность стафилококков, выделенных из крови // Научное обозрение. 2014. № 3. C. 184-189. [Kozlova N.S., Barantsevich E.P., Barantsevich N.E. Antibiotic resistance of staphylococci isolated from blood. Nauchnoe obozrenie = Scientific Review, 2014, no. 3. pp. 184-189. (In Russ.)]

3. Albrethsen J. Reproducibility in protein profiling by MALDI-TOF mass spectrometry. Clin. Chem., 2007, vol. 53, no. 5, pp. 852858. doi: 10.1373/clinchem.2006.082644

4. Böhme K., Fernández-No I.C., Barros-Velázquez J., Gallardo J.M., Cañas B., Calo-Mata P. Comparative analysis of protein extraction methods for the identification of seafood-borne pathogenic and spoilage bacteria by MALDI-TOF mass spectrometry. Analyt. Methods, 2010, vol. 2, no. 12, pp. 1941-1947. doi: 10.1039/C0AY00457J

5. Camoez M., Sierra J.M., Dominguez M.A., Ferrer-Navarro M., Vila J., Roca I. Automated categorization of methicillin-resistant Staphylococcus aureus clinical isolates into different clonal complexes by MALDI-TOF mass spectrometry. Clin. Microbiol. Infect., 2016, vol. 22, no. 2, pp. 161.e1-161.e7. doi: 10.1016/j.cmi.2015.10.009

6. Chen X.-P., Li W.G., Zheng H., Du H.Y., Zhang L. Extreme diversity and multiple SCCmec elements in coagulase-negative Staphylococcus found in the Clinic and Community in Beijing, China. Ann. Clin. Microbiol. Antimicrob., 2017, vol. 16: 57. doi: 10.1186/s12941-017-0231-z

7. Gibb S., Strimmer K. MALDIquant: a versatile R package for the analysis of mass spectrometry data. Bioinformatics (Oxford, England), 2012, vol. 28, no. 17, pp. 2270-2271. doi: 10.1093/bioinformatics/bts 447

8. Jamal W., Albert M.J., Rotimi V.O. Real-time comparative evaluation of bioMerieux VITEK MS versus Bruker Microflex MS, two matrix-assisted laser desorption-ionization time-of-flight mass spectrometry systems, for identification of clinically significant bacteria. BMC Microbiology, 2014, vol. 1, no. 14: 289. doi: 10.1186/s12866-014-0289-0

9. Lee M., Chung HS., Moon HW., Lee SH., Lee K. Comparative evaluation of two matrix-assisted laser desorption ionization time-of-flight mass spectrometry (MALDI-TOF MS) systems, Vitek MS and Microflex LT, for the identification of Grampositive cocci routinely isolated in clinical microbiology laboratories. J. Microbiol. Methods, 2015, vol. 113, pp. 13-15. doi: 10.1016/ j.mimet.2015.03.020

10. Patel R. MALDI-TOF MS for the diagnosis of infectious diseases. Clin. Chem., 2015, vol. 61, no. 1, pp. 100-111.

11. Ryan C.G., Clayton E., Griffin W.L., Sie S.H., Cousens D.R. SNIP, a statistics-sensitive background treatment for the quantitative analysis of PIXE spectra in geoscience applications. Nucl. Instrum. Methods Phys. Res. B., 1988, vol. 34, pp. 396-402. doi: 10.1016/0168-583X(88)90063-8

12. Schulthess B., Brodner K., Bloemberg G.V., Zbinden R., Böttger EPP., Hombach M. Identification of Gram-positive cocci by use of matrix-assisted laser desorption ionization-time of flight mass spectrometry: comparison of different preparation methods and implementation of a practical algorithm for routine diagnostics. J. Clin. Microbiol., 2013, vol. 51, no. 6, pp. 1834-1840. doi: 10.1128/ JCM.02654-12

13. Schulthess B., Bloemberg G.V., Zbinden R., Böttger E.C., Hombach M. Evaluation of the Bruker MALDI Biotyper for identification of gram-positive rods: development of a diagnostic algorithm for the clinical laboratory. J. Clin. Microbiol., 2014, vol. 52, no. 4, pp. 1089-1097. doi: 10.1128/JCM.02399-13

14. Schuster D., Josten M., Janssen K., Bodenstein I., Albert C., Schallenberg A., Gajdiss M., Sib E., Szekat C., Kehl K., Parčina M., Hischebeth G.T.R., Bierbaum G. Detection of methicillin-resistant coagulase-negative staphylococci harboring the class A mec complex by MALDI-TOF mass-spectrometry. Int. J. Med. Microbiol., 2018, vol. 308, no. 5, pp. 522-526. doi: 10.1016/j.ijmm.2018.05.001

15. Seng P., Fournier PE., La Scola B., Drancourt M., Raoult D. MALDI-TOF-mass spectrometry applications in clinical microbiology. Future Microbiol., 2010, vol. 5, no. 11, pp. 1733-1754. doi: 10.2217/fmb.10.127

16. Staphylococcus aureus subtyping for MRSA detection. URL: https://www.bruker.com/products/mass-spectrometry-and-separations/maldi-biotyper-for-microbiological-research/mbt-subtyping-software-module/staphylococcus-aureus-subtyping-for-mrsa-detection.html (21.11.2017) 
17. Wang H.-Y., Lee T.Y., Tseng Y.J., Liu T.P., Huang K.Y., Chang Y.T., Chen C.H., Lu J.J. A new scheme for strain typing of methicillin-resistant Staphylococcus aureus on the basis of matrix-assisted laser desorption ionization time-of-flight mass spectrometry by using machine learning approach. PLoS One, 2018, vol. 13, no. 3, pp. e0194289. doi: 10.1371/journal.pone.0194289

18. Westblade L.F., Garner O.B., MacDonald K., Bradford C., Pincus D.H., Mochon A.B., Jennemann R., Manji R., Bythrow M., Lewinski M.A., Burnham C.-A.D., Ginocchio C.C. Assessment of reproducibility of matrix-assisted laser desorption ionization-time of flight mass spectrometry for bacterial and yeast identification. J. Clin. Microbiol., 2015, vol. 53, no. 7, pp. $2349-2352$. doi: $10.1128 / J C M .00187-15$

19. Wolters M., Rohde H., Maier T., Belmar-Campos C., Franke G., Scherpe S., Aepfelbacher M., Christner M. MALDI-TOF MS fingerprinting allows for discrimination of major methicillin-resistant Staphylococcus aureus lineages. Int. J. Med. Microbiol., 2011, vol. 301, no. 1, pp. 64-68. doi: 10.1016/j.jimm.2010.06.002

\section{Авторы:}

Степанов А.С., ассистент кафедры медицинской микробиологии ФГБОУ Северо-Западный государственный медицинский университет им. И.И. Мечникова,

Санкт-Петербург, Россия;

Васильева И.В., д.б.н., профессор, зав. кафедрой медицинской микробиологии ФГБОУ Северо-Западный государственный медицинский университет им. И.И. Мечникова, Санкт-Петербург, Россия.

\section{Authors:}

Stepanov A.S., Assistant Professor, Department of Medical Microbiology, North-West State Medical University named after I.I. Mecluiikov, St. Petersburg, Russian Federation;

Vasilyeva N.V., PhD, MD (Biology), Professor,

Head of the Department of Medical Microbiology, North-West State Medical University named after I.I. Mecluiikov, St. Petersburg, Russian Federation. 